\title{
Fair Values: A Framework For Teaching The Standards On Accounting For Financial Instruments
}

\author{
Michael O. Mensah (email: mom352@uofs.edu), University of Scranton \\ Huldah A. Ryan (email: hryan@iona.edu), Iona College \\ Hong V. Nguyen (email: Nguyen@uofs.edu), University of Scranton
}

\begin{abstract}
This paper presents a conceptual framework for an integration of financial reporting objectives and principles related to financial instruments. We believe this integrated approach to be a superior strategy for discussing this diverse and challenging topic. In our experience, the typical piecemeal coverage of individual instruments scattered in financial accounting texts and other literature is not effective in providing students with a critical appreciation of the evolution in financial reporting requirements in this area. Our approach in this paper is to classify financial instruments into groups according to their special characteristics as a basis for understanding their relevant financial reporting attributes. Within this conceptual framework, we then present a synthesis of reporting objectives and existing FASB pronouncements on financial instruments. Using this framework as a roadmap, students should be able to study current and emerging pronouncements in a conceptually organized and integrated fashion.
\end{abstract}

\section{Introduction}

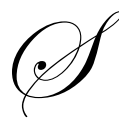

ince the early1990s, the Financial Accounting Standards Board (FASB) has issued several statements of accounting standards on financial instruments. These include SFAS 105-Disclosure of Information about Financial Instruments With Off-Balance Sheet Risk and Financial Instruments With Concentrations of Credit Risk, SFAS 107-Disclosures About Fair Values of Financial Instruments, SFAS 115-Accounting for Certain Investments in Debt and Equity Securities, SFAS 119-Disclosure about Derivative Financial Instruments and Fair Value of Financial Instruments, and SFAS 133-Accounting for Derivative Instruments and Hedging Activities. These new standards constitute the FASB's ongoing efforts at improving financial reporting for this broad class of diverse assets and liabilities. These efforts are partly in response to the numerous financial contracts being created by recent innovations in financial markets. Because of the fast pace of this innovation and the complexity and diversity of the resulting financial contracts, the FASB issued many standards as stop-gap measures usually emphasizing disclosure, while it pondered weightier questions of recognition and measurement. This has led to many confusing amendments and modifications. For example, SFAS 105 requirements have been folded into SFAS 107, and SFAS 119 has been completely replaced by SFAS 133 . These continuous changes have added to the difficulties related to teaching and learning accounting in this area. An integrated view of financial reporting objectives, concepts, principles, and requirements is not easily obtained from reading individual standards. Additionally, students find it difficult to understand this view from the fragmented treatments usually given in financial accounting texts.

The conceptual approach taken in this paper is: (1) to identify and classify financial instruments based on their special attributes; (2) to link these attributes to financial reporting goals and objectives in this area; and (3) to provide a summary and synthesis of accounting standards issued to date on financial instruments. This conceptual

Readers with comments or questions are encouraged to contact the authors via email. 
and integrated discussion and analysis approach should be a useful tool for teaching and learning current and emerging reporting standards on financial instruments.

\section{Identification Of Financial Instruments}

The FASB (1991) defines financial instruments as follows:

1. Cash, including domestic and foreign currency and demand deposits.

2. Evidence of an ownership interest in an entity, including common and preferred stock options, and warrants to buy such stock.

3. Any contract that creates an obligation for one entity to deliver cash to a second entity which is accorded a contractual right to receive that cash. This would include trade accounts, promissory notes, loans, and bonds.

4. Any contract that creates an obligation for one entity to deliver a financial instrument to a second entity, which has a contractual right to receive that instrument. An example of this would be a promissory note, which an issuer is obligated to settle by the delivery of specified units of a U.S government security.

5. Any contract that creates an obligation for one entity to exchange financial instruments on potentially unfavorable terms with a second entity that has a contractual right to the exchange on potentially favorable terms. This would include forward contracts, in which two entities agree to exchange a specified amount of a security or currency at a specified date, and at a predetermined exchange rate.

Securities and other contracts that qualify as financial instruments under this definition are numerous, and financial markets are creating more each day. It is therefore useful to recognize the following characteristics that are common to all items in the group for practical identification purposes. These characteristics are also useful for identifying financial measurement and disclosure principles useful for fulfilling reporting objectives in this area:

1. Financial instruments create actual or potential assets and liabilities or equities for holders and issuers and are therefore relevant to presenting a fair view of financial position for such entities.

2. These assets and liabilities consist of rights to receive, or obligations to pay cash, that are determined by contractual or other legal terms as opposed to an entity's own production and service activities.

3. The specific amounts and timing of future cash receipts or payments may be fixed by contract terms or determined by contingent factors.

4. The ultimate value of a financial instrument is usually affected by external risk factors, including credit risk and market risk. Credit risk is the probability that a contract counter party will be unable to settle its obligation when due. Market risk is the probability that future market factors (such as stock prices, currency exchange rates, and interest rates) will affect the ultimate amount of cash paid or received.

5. As a result of these risks, entities holding financial instruments as assets or liabilities may experience holding or realized gains and losses.

Table 1 provides a broad view of financial instruments in contrast to other balance sheet items. It classifies balance sheet items by two broad criteria: (1) whether the future cash flows from the item will involve the firm's operations, and (2) whether the future cash flows of the item are measurable in fixed contractual dollars.

Panels A and B in Table 1 include financial instruments, while Panels C and D encompass all other balance sheet items. Further, items in Panel A represent financial assets and liabilities whose future cash flows are fixed in terms of contractual dollars while the future cash flows of financial items in Panel B are not determinable in contractual dollars. Similarly, for non-financial instruments, Panel C contains operational items whose future benefits are not determinable in contractual dollar amounts, while Panel D describes operational items that can be measured in contractual dollar amounts. 
Table 1

Financial Instruments Contrasted With Other Balance Sheet Items

\begin{tabular}{|c|c|c|}
\hline & $\begin{array}{l}\text { Amounts of } \quad \text { Benefits } \quad \text { or } \\
\text { Obligations } \\
\text { Dollars. }\end{array}$ & $\begin{array}{l}\text { Future Amounts of Benefits or Obligations Not Measurable } \\
\text { in Fixed Dollars. }\end{array}$ \\
\hline $\begin{array}{l}\text { Benefits and } \\
\text { Obligations are Direct } \\
\text { and Financial. }\end{array}$ & $\begin{array}{l}\text { Cash } \\
\text { Accounts Receivable/Payable } \\
\text { Notes Receivable/Payable } \\
\text { Bonds Payable at Maturity } \\
\text { Loans Receivable/Payable } \\
\text { Investments in Debt Securities } \\
\text { Held-to-Maturity Securities. }\end{array}$ & $\begin{array}{l}\text { (B) } \\
\text { Investments in Equity Securities. } \\
\text { Investments in Debt Securities Not Held to Maturity. } \\
\text { Derivatives - Interest Rate Options and Forward and } \\
\text { Futures Contracts. } \\
\text { Interest Rate Caps and Floors } \\
\text { Interest Rate Swaps. }\end{array}$ \\
\hline $\begin{array}{l}\text { Benefits and obligations } \\
\text { Indirect and } \\
\text { Operational. }\end{array}$ & $\begin{array}{l}\quad \quad(\mathrm{C}) \\
\text { Prepaid Expenses } \\
\text { Advances to Suppliers } \\
\text { Deferred Revenues } \\
\text { Warranty Obligations } \\
\text { Commodity Futures. }\end{array}$ & $\begin{array}{l}\text { Inventories } \\
\text { Property, Plant and Equipment. }\end{array}$ \\
\hline
\end{tabular}

Table 2 provides a framework for assessing the risks associated with typical financial instruments classified into groups according to the determinability of cash receipts and cash payments. It also shows the credit and market risks faced by issuers and holders of the financial instruments. The classification should be useful in recognizing the diversity of financial instruments and their varying degrees of complexity despite the unifying factors listed above.

Panel A of Table 2 shows examples of financial instruments that assign rights and impose obligations involving definite contractual future cash amounts and specific timing for delivery or receipt of cash. These are traditional financial instruments whose cash flows are normally subject to the risk of default by the issuer. Furthermore, items such as bonds and redeemable preferred stocks may also be subject to interest rate risk when traded before maturity.

Panel B shows examples of financial instruments that convey rights and impose obligations involving determinable contractual future cash amounts. However, these rights and obligations are contingent on specific future events such as the default of a third party on a loan made by the holder of the financial instrument. The issuer of financial instruments such as financial guarantees faces the possibility of loss due to the defaults of the entity whose credit has been guaranteed.

Many of the financial instruments listed in Panel $\mathrm{C}$ are the result of fairly recent developments in financial markets. Financial contracts such as options, swaps, futures, and forwards have been created to diversify investment opportunities or opportunities for hedging risks associated with other financial instruments. These instruments, called derivatives, derive their market value from changes in the price of a stock, changes in a stock index, the exchange rate of a currency, or changes in interest rates. For example, the value of a forward contract to buy a foreign currency at a predetermined exchange rate changes as market exchange rates for the underlying currency changes. This market risk can result in accounting losses or gains for either counterparty to the contract.

Panel D of Table 2 shows examples of financial instruments that represent equity interests in another entity. These instruments give the holders the right to pro-rata shares in dividends if declared, and in the residual net assets of the entity issuing the financial instrument. Traditionally, these instruments have been accounted for at cost or the lower of cost or market value. 
Table 2

A Framework for Assessing the Risks Associated With Typical Financial Instruments

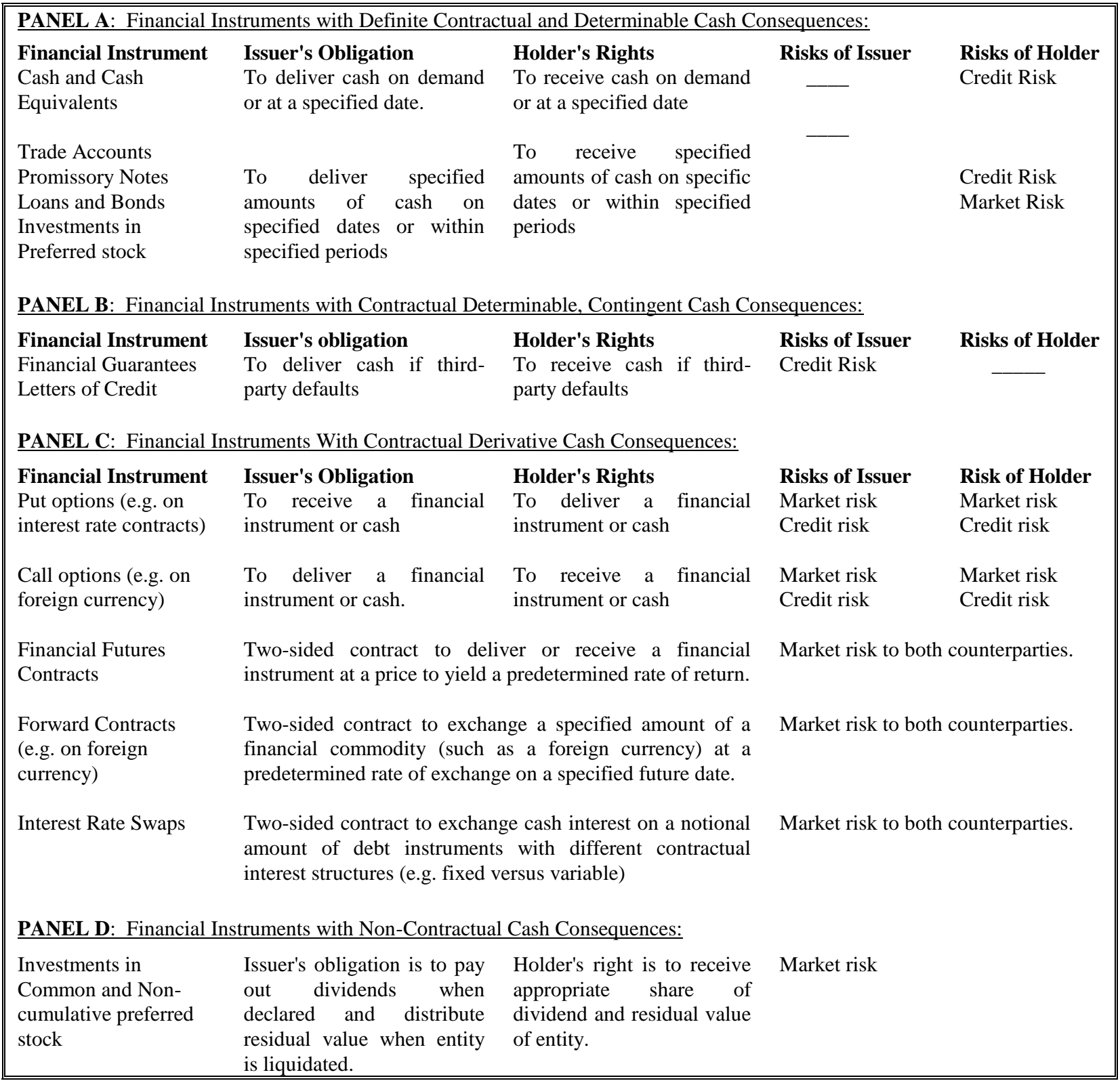

\section{Financial Reporting Objectives}

A major objective of financial reporting is to select, measure, and report appropriate attributes of financial statement elements useful for assessing the future cash consequences of an entity's financing and investment decisions (FASB Concepts: No. 1). Current finance theories suggest that the most relevant attribute of any financial instrument is the current risk-adjusted present value of the estimated cash to be received or paid under the contract. The major objective of financial reporting for a financial instrument, under this view, is to estimate the amounts and timing of its future cash flows and its present value using a discount rate that reflects the cost of capital and the credit and market risks associated with such cash flows. Periodic changes in these present value amounts should then be 
recognized on the balance sheet and reflected in income. However, the future cash consequences of financial instruments can often be directly realized via transactions in organized securities markets if traded. Furthermore, empirical studies report that current market value information and the credit and market risks associated with a particular instrument appear to provide incremental value-relevant information, over and above other measurements, such as historical cost variables (Barth, 1994; Eccher et al., 1996). These issues appear to have impacted the FASB's efforts at prescribing accounting standards for financial instruments. The overall strategy adopted by the FASB is based on the premise that fair value disclosures and measurements of these instruments is the best approach for dealing with the quickly evolving areas of financial innovation.

\section{The Concept Of Fair Value}

The FASB defines the fair value of a financial instrument as:

"the amount at which the instrument could be exchanged in a current transaction, between willing parties, other than in a forced or liquidation sale" (FASB, 1991 par 5).

It is useful to interpret this definition within the context of the objectives of financial reporting discussed above. The FASB's definition emphasizes the perceived advantages of using current market-determined estimates such as current selling prices in determining fair value. Because such numbers are independently determined, they eliminate the need for subjective determinations of balance sheet values that undermine reliability and comparability, and also provide discipline in financial reporting.

The availability of relevant information for estimating the future cash consequences of financial instruments varies between instruments and the entities that report them. As a result, a variety of fair value estimators with different degrees of predictive ability and verifiability may be feasible for different situations. Some financial instruments are regularly traded on organized auction or over-the-counter markets and their quoted market prices are usually available in the form of daily closing, dealers bid and ask, or dealer mid-point prices. These market prices are the most recommended estimates of fair value for financial instruments because they represent the unbiased market consensus regarding probable future cash amounts, and discount rates reflecting the cost of capital and risks associated with the future flows. Such market prices are also verifiable.

Other financial instruments (such as notes payable/receivable) are originally recorded at their future contractual settlement amounts, and fair value can be approximated by recorded face amount, net realizable value, or amortized value, as they approach maturity. These approximations are especially justified during stable economic conditions when market and credit risks are immaterial. For customized financial instruments that are not publicly traded, fair values may be estimated from finance models such as the Black and Scholes (1973) option-pricing model, from present value models when the amounts and timing of contractual cash flows involved in the instrument are readily available, or from appraisal values of pricing specialists such as firms offering loan-pricing services.

\section{Specific Fair Value Accounting And Disclosure Requirements For Financial Instruments - An Integration}

The specific accounting requirements for financial instruments continue to evolve. Currently, the requirements are set out mainly in SFAS 107, which covers fair value disclosures for all financial instruments, SFAS 115, which focuses on certain investments, and SFAS 133, which addresses accounting requirements for derivatives. SFAS 133 has replaced the original interim disclosure requirements of SFAS 105 and 119. Table 3 summarizes current disclosure and accounting measurement requirements, up to the issuance of SFAS 133, from the general to the specific in nature. 
Table 3

Summary of Current Reporting Requirements for Financial Instruments

\begin{tabular}{|l|l|}
\hline Type Of Financial Instrument & Required Disclosures \\
\hline All Financial Instruments & $\begin{array}{l}\text { Disclose fair value of financial instrument if } \\
\text { practicable to do so. (Quoted market prices are } \\
\text { most desirable) } \\
\text { Disclose methods and assumptions used to estimate } \\
\text { fair value in absence of quoted market prices. } \\
\text { Disclose all material concentrations of credit risk. }\end{array}$ \\
\hline Type Of Financial Instrument & Recognition And Measurement \\
\hline $\begin{array}{l}\text { Non-Derivative Financial Instruments (Except } \\
\text { Trading and Available-for-Sale investments). }\end{array}$ & $\begin{array}{l}\text { Measurement at cost, amortized cost, future } \\
\text { settlement amounts, as appropriate. }\end{array}$ \\
\hline Trading and Available-for-Sale Securities & $\begin{array}{l}\text { Measurement at cost and adjusted to fair value. } \\
\text { Recognize gains and losses in current income for } \\
\text { Trading securities, and in comprehensive income } \\
\text { for Available-for-Sale securities. }\end{array}$ \\
\hline $\begin{array}{l}\text { Non-Hedge Derivative Financial Instruments } \\
\text { vecognize as asset or liability. Measurement at fair } \\
\text { Income. Report gains and losses in current ordinary }\end{array}$ \\
\hline $\begin{array}{l}\text { Derivative Designated as Hedge of Fair Value for a } \\
\text { Recognized Asset or Liability }\end{array}$ & $\begin{array}{l}\text { Recognize as asset or liability. Report gains and } \\
\text { losses from derivative and hedged item in current } \\
\text { income. }\end{array}$ \\
\hline $\begin{array}{l}\text { Derivative Designated as Hedge of Cash Flow of } \\
\text { Forecasted Transaction or Foreign Exchange } \\
\text { Denominated Transaction }\end{array}$ & $\begin{array}{l}\text { Recognize as asset or liability at fair value. Report } \\
\text { gains and losses of effective and ineffective hedges } \\
\text { in comprehensive income and current income } \\
\text { respectively. }\end{array}$ \\
\hline $\begin{array}{l}\text { Derivative Designated as Hedge of Foreign } \\
\text { Currency Exposure of Net Investment in Foreign } \\
\text { operations. }\end{array}$ & $\begin{array}{l}\text { Recognize as asset or liability at fair value. Report } \\
\text { gains and losses as part of comprehensive income. }\end{array}$ \\
\hline
\end{tabular}

Disclosures: In addition to disclosures of estimated fair values, the standards on accounting for financial instruments require disclosures about concentrations of credit risk, the possibility that "a number of contract counterparties are engaged in similar activities and have similar economic characteristics that would cause their ability to meet contractual obligations to be similarly affected." (SFAS 107, as amended). Any information useful in assessing the nature of the concentration and amounts that can be lost through the default of contract counterparties should be disclosed. These disclosure requirements cover all items in Panels A through D of Table 2.

Recognition and Measurement: For non-derivative financial instruments identified in Panel A of Table 2, traditional measurement bases have included cost, amortized cost, net realizable value, and settlement amounts, as appropriate. These measurements are still reportable as long as fair values are also provided when different from book values at the balance sheet date.

For investments in equity securities identified in Panel D of Table 2, SFAS 115 - Accounting for Certain Investments in Debt and Equity Securities - replaces SFAS 12 and is a part of the logical progression of the financial instruments project. The standard requires that all debt securities be classified into three portfolios - those held for trading purposes, those held as available-for-sale securities, and those debt securities which management has the intent and purpose to hold to maturity. Investments in equity securities are to be classified into trading or available- 
for-sale portfolios. In the balance sheet, all trading and available-for-sale securities are reported at fair value with unrealized gains and losses reported in the associated income statement for trading securities and as adjustments to stockholders' equity for available-for-sale securities. Held-to-maturity investments in debt securities are reported at amortized cost, with fair value disclosures as mandated by SFAS 107.

Finally, SFAS 133 - Accounting for Derivative Instruments and Hedging Activities - focuses on derivative instruments, including those embedded in other contracts, and hedging activities. It requires that all entities recognize all derivatives as assets or liabilities and disclose them at fair value. For a derivative not designated as a hedge of an existing asset or liability, periodic changes in fair value should be reported in current ordinary income as gains or losses. For a derivative that is properly designated as a hedge of an existing asset or liability (fair value hedge), the statement requires that gains and losses from the derivative and the hedged item be reported in current income.

Some derivatives such as foreign currency forward contracts may be acquired in order to hedge against the cash flows of a forecasted future transaction or foreign currency denominated transaction. For these cash flow hedges, gains and losses are reportable in current income to the extent that the hedge was successful in saving cash flows (effective hedges). Otherwise, gains and losses are reportable in comprehensive income until the transaction is consummated, at which time they move into income. Lastly, for derivatives acquired to hedge net investments in foreign operations, gains and losses are reportable in comprehensive income.

\section{Summary And Conclusion}

Our discussion on reporting concepts and the specific accounting standards for financial instruments examines the evolution of fair value as the basis for reporting on financial instruments. This article also presents a framework that can be used as a practical tool for teaching and learning existing and emerging standards on financial instruments. It identifies financial instruments, including the basic ones which can be defined in terms of assets, liabilities, and owners' equity, and the derivative instruments which may be based on contingent events and may require special treatment. The financial instruments are then classified according to their common attributes, in keeping with the financial reporting objectives that apply to them.

This study examines fair value, prescribed by the FASB, as the basis for the valuation of financial instruments. Currently, fair value information in the statement of financial position is required for most classes of financial instruments listed in Table 2. This requirement is in response to the need to: simplify financial reporting in this area to a considerable degree; reduce management manipulation by reducing activities in gains trading; and make financial statements more comparable, relevant, and reliable. Additional objectives include the need to make financial statements more complete, and investors more fully informed about the financial position of the firm. The objective of this study is to simplify the understanding of the standards on accounting for financial instruments. We hope that the framework developed will be used as a teaching tool about the nature of these standards, the risks associated with the different financial instruments, and the uniform ways in which they can be reported in the financial statements. Further empirical investigation of the effects of fair value reporting and disclosures of financial instruments on firm value could be a fruitful avenue for research in the future.

\section{References}

1. Ahmed, A., and C. Takeda .1995. Stock Market Valuation of Gains and Losses on Commercial Banks' Investment Securities: An Empirical Analysis. Journal of Accounting and Economics 20: 207-225.

2. Barth, M.E. 1994. Fair Value Accounting: Evidence from Investment Securities and the Market Valuation of Banks. The Accounting Review 69: 1-25.

3. _ W. Landsman, and J. Wahlen. 1995. Effects of Bank Earnings Volatility, Regulatory Capital, and Valuation Contractual Cash Flows. Journal of Banking and Finance 19: 577-605.

4. _ W. Beaver, and W. Landsman. 1996. Value-Relevance of Banks' Fair Value Disclosures Under SFAS No. 107. The Accounting Review 71: 513-537. 
5. Beatty A., S. Chamberlain, and J. Magliolo. 1996. An Empirical Analysis of the Economic Implications of Fair Value Accounting for Investment Securities. Journal of Accounting and Economics 22: 43-77.

6. Black, F., and M. Scholes. 1973. The Pricing of Options and Corporate Liabilities. Journal of Political Economy (May/June): 637-654.

7. Cornett, M., Z. Rezae, and H. Tehranian. 1996. An Investigation of Capital Market Reactions to Pronouncements on Fair Value Accounting. Journal of Accounting and Economics 22:119-154.

8. Dechow, P., R. Sloan, and A. Sweeney. 1995. Detecting Earnings Management. The Accounting Review (April): 193-225.

9. Eccher, E., K. Ramesh, and S. Thiagarajan. 1996. Fair Value Disclosures by Bank Holding Companies. Journal of Accounting and Economics 22: 79-117.

10. Financial Accounting Standards Board (FASB), 1990, Statement No. 105: Disclosure of Information about Financial Investments with Off-Balance-Sheet Risk and Financial Instruments with Concentrations of Risk. FASB.

11. _ 1991, Statement No. 107: Disclosures about Fair Value of Financial Instruments. FASB.

12. _ 1993, Statement No. 115: Accounting for Certain Investments in Debt and Equity Securities. FASB.

13. _ 1994, Statement No. 119: Disclosure about Derivative Financial Instruments and Fair Value of Financial Instruments. FASB.

14. _ 1996, Exposure Draft: Accounting for Derivative and Similar Financial Instruments and for Hedging Activities. FASB.

15. Harper, R., W. Mister, and J. Strawser. 1991. The Effect of Recognition Versus Disclosure of Unfunded Postretirement Benefits on Lenders' Perceptions of Debt. Accounting Horizons (September): 50-56.

16. Healy, P. 1985. The Effect of Bonus Schemes on Accounting Decisions. Journal of Accounting and Economics (April): 85-107.

17. Lewellen, W., T. Park, and T. Byung. 1996. Self-Serving Behavior in Managers' Discretionary Information Disclosure Decisions. Journal of Accounting and Economics 22:227-251.

18. Nelson, K. 1996. Fair Value Accounting for Commercial Banks: An Empirical Analysis of SFAS 107. The Accounting Review (April): 161-182.

19. Petroni, K., and J. Wahlen. 1995. Fair Values of Equity and Debt Securities and Share Prices of PropertyCasualty Insurance Companies. Journal of Risk and Insurance 62, (December). 